\title{
内耳の再生医療
}

\section{特集 Tissue engineering をべースとした組織再生誘導治療}

\section{伊 藤 壽 一*}

Regeneration of the inner ear

This paper reviews the potential of cell transplantation to restore inner ear hair cells. Histological analysis revealed survival and incorporation of grafted stem cells in various portion of the inner, suggesting the ability of stem cells for differentiation into inner ear hair cells.

内耳の有毛細胞の障害が高茇難㯖や高度平衡機能障害を引き起こす，従来，哺乳類の内耳有毛練胞 は、一度障害を受けると回復は困難であると考えられてきた。各種幹細胞を内耳に移植することによ り，内耳有毛細胞を再生させることに成功した，さらに，DDSの技術を用い，内耳へ神経栄菻因子 などを投与することも可能になった。これらの方法を組み合わせることにより，障害を受けた内耳を 再生させることは可能であると思われる。

Juichi Ito* key words : inner ear; regeneration, stem cell, transplantation, drug delivery system

再生医学は障害を受けた器官・組織を修復し, 機 能も回復しょうとするものであり，医学の分野では 21 世紀前半の最大のプロジェクトと考えられてい る. 再生医学がすでに臨床応用されている分野もあ る. 造血幹細胞を利用した骨髄移植や角膜移植など 多岐にわたる，その他，再生医学により動物実験の 段階ではすでに作製が可能なものに，血管，心筋細 胞, 骨組織, 軟骨組織, ドーパミン産生神経細胞など 多分野にわたるものを列挙することが出来る.

耳鼻咽喉科・頭頸部外科学の分野での再生医学は 比較的最近研究がはじまったといえる、ヒトを含め 哺乳類の感覚器細胞はこれまで，一度障害を受ける と再生は困難であり, 機能回復はしないと考えられ てきた、そのため, 耳科学の分野では，中耳までの 伝音難聴は治療の対象になるが, 内耳の障害, 特に 高度感音難聴や高度内耳障害による平衡機能障害な どの, 感覚細胞 (有毛細胞)の障害に起因する疾患は 有効な治療手段がなかった. 内耳の有毛細胞も一度 障害を受けると再生しないと考えられ，このことが 特に内耳の有毛細胞の障害に起因することの多い感 音難聴の治療の困難さの原因とされている.

\footnotetext{
* Department of Otolaryngology Head and Neck Surgery, Graduate School of Medicine, Kyoto University 京都大学大学院医学研究科 耳鼻咽喉科・幁顠部外科学
}

しかし，哺乳類の中枢神経系でも再生能力が有 することがわかってきた，再生能力はあり，障害を 受けても再生しようとする徴候はみられるが, 再生 を妨げる因子が働き，結局は再生しないと説明され ている.内耳の有毛細胞も障害を受けるとまったく 再生しないと考えられてきたが，鳥類ではある程度 の再生が認められ ${ }^{1)}$, 哺乳類でも前庭器の感覚細胞 は多少再生するとの報告がみられるようになってき た2)

再生医学を内耳に応用する場合, 現段階ではい くつかの方法があると考えられる。一つは“自発的 再生の誘導” である. この自発的再生は発生, 細胞 死とも関連するが, 内耳発生の分子機構を解明し, それを内耳障害の治療に応用しようとする試みであ る.

一方，筆者らはこのような自発的再生を促進する 研究と並行して, “細胞移植”による内耳再生を試 みた，具体的には種々の幹細胞を障害を受けた内耳 に移植し, 有毛細胞その他の細胞の再生に応用しょ うとする試みである.内耳障害を組織学的に観察す ると, 最も障害を受けやすいのは内耳有毛細胞であ る、まず, 有毛細胞が障害を受けるが, 初期の段階 では有毛細胞以外の周用環境 (支持細胞なども含め) は，比較的正常に保たれている場合が多いと考えら 
れる. 単純に考えれば, 有毛細胞を再生することが 出来れば, 内耳機能も回復するのではないかという 発想である。

細胞移殖による内耳再生医療に関し, 当初は有毛 細胞の再生を念頭において研究をはじめたが,この ような方法が他の付随的な結果を生み出すことが判 明した，動物の内耳に移植した，特に神経幹細胞の 多くのものがグリア系の細胞に分化し，神経栄養因 子を産生する可能性が認められた ，神経栄荃因子 のなかには, 有毛細胞の障害に対し, 保護作用を有 するものがあり，内耳に移植した神経幹細胞が，結 果的に障害を受けた有毛細胞の機能を回復させる可 能性を示唆する所見が得られた。

他の成果は, 蝸牛軸の方向に移植した幹細胞が神 経細胞に分化したことである. 現在, 高度難聴に対 する唯一の治療法は人工内耳であるが, 人工内耳手 術を行ってもらせん神経節細胞が障害を受けていれ ば，信号を中枢に送ることは出来ず，また送る信号 が限られ，結果的には良好な聞き取りが得られない. 特に内耳奇形例で，らせん神経節細胞の障害が推定 される場合は，人工内耳手術後の言葉の聞き取りも 不良な例が多い ${ }^{4)}$ 。幹細胞移植により，らせん神経 節細胞が再生し, 内耳有毛細胞や脳幹の蝸牛神経核 細胞に神経連絡をつくることが出来れば，人工内耳 での聞き取りも飛躍的に増大すると期待される.

\section{内耳障害の現状}

現在, わが国には補聴器も使用できない高度難聴 者および熋者が数 10 万人存在し, また, 補聴器に よりかろうじて聴覚が得られる難聴者を加えると, 高度聴覚障害者の数は数 100 万人に達すると推測 される、また, 内耳障害に起因する平衡機能障害者 はその総数が把握できないほどである，高度難聴者 のコミュニケーション手段は聴覚以外の方法一筆 談, 手話などに頼っている.

このような高度難聴の原因は, 内耳および中枢聴 覚路の老化, 騒音による障害, 抗生物質や抗がん剤 などの種々の薬物による障害など多岐にわたる，い ずれの原因にせよ，これらの高度感音難聴に対する 有効な治療手段はほとんどない。感音難聴の原因は
さまざまであるが, 病態としては大部分が内耳の有 毛細胞の障害である. 有毛細胞の再生が可能となれ ば, 一度喪失した聴覚の再獲得も可能と思われる. 従来, 内耳有毛細胞を含め, 哺乳類の中枢神経系 は，一度障害を受けると再生は困難とされてきた。

しかし，最近では障害を受けた哺乳類の中枢神経系 でも条件さえよければ再生する系もあるという報告 がある.さらに, 胚性幹細胞や神経幹細胞の分離が 可能となり，神経移植のドナーとして利用し，障害 を受けた中枢神経系の再生を試みる報告もある，各 種神経成長因子を中枢神経系に投与し，障害を受け た中枢神経系が修復されたとする報告もある。

内耳再生医療の目的は, 各種神経成長因子や幹細 胞を利用して，障害を受けた内耳有毛細胞や中枢聴 覚路の再生を試みることである.

\section{内耳障害の病態}

内耳障害の病態を考えるに, 最も障害を受けやす いのが内耳の有毛細胞であり,さらに有毛細胞から の信号を中枢に伝えるらせん神経節細胞，また内耳 のイオン組成を調節するといわれる血管条細胞の障 害も内耳機能低下をきたす.このなかでも最も重要 なものは有毛細胞であり，障害を受けた有毛細胞が 再生すれば失われた内耳機能も回復するのではない かと考えられる.

従来, 鳥類, 哺乳類では, 内耳有毛細胞が形成さ れるのは発生の過程に限られ, 出生後は内耳有毛細 胞が一度傷害されると再生することはないとされて きた.しかし，1980年代後半に，鳥類では前庭の 有毛細胞は常に再生をしており ${ }^{5)}$, 聴覚系の有毛細 胞も再生されることが明らかにされた ${ }^{6)}$. 哺乳類に おいても，蝸牛における有毛細胞の再生はいまだに 証明されていないものの, 前庭の有毛紐胞は再生す ることが明らかにされている

\section{内耳有毛細胞の自発的再生}

内耳の特に有毛細胞の自発再生を考える際, 以下 の三つの機構があげられる.

(1) 有毛細胞の周囲にある支持細胞が細胞分裂に 
つづく細胞増殖を起こし, 有毛細胞が形成さ れる.

(2) 支持細胞が性質を変えて有毛細胞に分化転換 する.

(3) 完全に死に至っていない有毛細胞が自己修復 する.

各国の内耳再生を研究する施設の多くは，この自 発的再生を促進しようとする研究を行っている.

鳥類を用いた実験では, 有毛細胞の再生の過程 でDNAの複製が支持細胞に認められることから, 支持細胞あるいはそのなかの一部の細胞の非対称的 な有系分裂により，有毛細胞が再生するとされてい た8)、しかし、哺乳類においては, 障害後の有毛細 胞の再生の過程で DNAの複製を確認できる細胞が 認められるものの, その数は非常に少なく有毛細胞 の再生を担うほどではないと考えられている99.

有糸分裂を介さない内耳有毛細胞の再生の機構 の一つとして, 支持細胞が直接有毛細胞に変わる 分化転換が, 両生類, 鳥類, 哺乳類においていわれて いる. その根拠は形態学的なもので, 上皮の基底面 から頂上面に至るまで, 細胞体が存在する支持細胞 の特徵と, 微䋐毛を有するという未熟な有毛細胞の 特徵を兼ね備えた細胞が観察されるというものであ る. 分化転換による内耳再生の利点として, 有糸分 裂によるものと比較して短期間での再生が可能であ る点が考えられている.

これらに対し，内耳障害後の哺乳類における有 毛細胞の再生を担っているのは, 完全死に至ってい ない有毛細胞による自己修復であるという考えがあ る. 自発的な内耳有毛細胞の再生を誘導する因子に ついての研究は, 成長因子やホルモンなどの細胞外 から作用を及ぼす外因性の物質が中心であったが, 分子生物学の発展やさまざまな遗伝子の発見によ り, 内耳有毛細胞再生を促す細胞内のメカニズム や内耳感覚上皮細胞の動態が解明されようとしてい る.さらなる解析が進めば, 従来不可能とされてい た内耳有毛細胞再生の誘導を促す手法の発見・開発 につながると思われる.

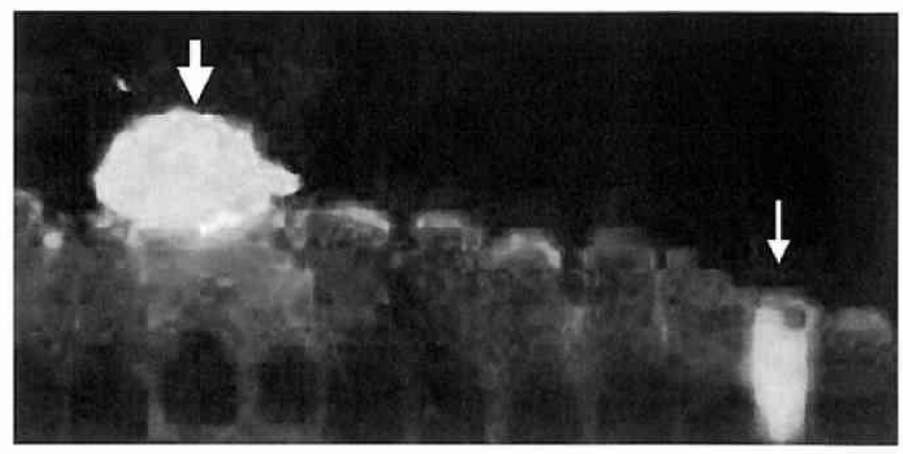

図1神経幹細胞の内耳移植

ラット内耳に神経幹細胞を移植後の綃牛上皮, 感覚上皮の 上(太矢印)に移植細胞が监状に生着している。一部の細胞 (細矢印)は蝸牛の感喾上皮内に入り込んで有毛細胞に置き換 わっているように見える.

\section{細胞移植による内耳再生}

内耳有毛細胞の再生を考えた場合，自発再生を促 すことも一つの方法であるが，実際にはまだ困難な 面が多い，そこで筆者らは細胞移植の方法を用い， 内耳再生を試みた。

内耳障害に対し，細胞移植による治療を目指す 際，克服しなくてはいけないいくつかの課題があ る. 最大の課題は移植材料の開発である. 移植材料 には幹細胞を利用することを考えているが, 幹細胞 にもいくつかの種類・段階がある．どの幹細胞を用 いるべきなのかが問題となる，移植細胞の候補にあ がるのは, 胚性幹細胞 (ES 細胞), 神経幹細胞, 内耳 幹細胞, 間葉系幹細胞である.

ES 細胞はすべての組織・器官のもとになる細胞 であり，全能細胞ともいわれる． ES 細胞から神経 細胞に誘導するおおよその方法が確立されている が, 内耳有毛細胞への誘導に関してはまったくまた 研究がなされていない. ES 細胞を内耳への移植材 料として用いて, 果たして内耳の環境のなかで分化 の方向に向かうかは疑問視される.内耳が外胚葉由 来であることを考えると，ES 細胞を外胚葉方向に 誘導した細胞を使用するのも一つの方法である.

神経幹細胞はすでに実験的に内耳で生着し，一 部内耳有毛細胞に分化することが確かめられており $(\text { 図 1 })^{10)}$ ，今後も移植材料としての可能性は高い.

これらの幹細胞にくらべ, 内耳幹細胞が実際に存 在し, 分離できれば内耳感覚細胞への分化という意 

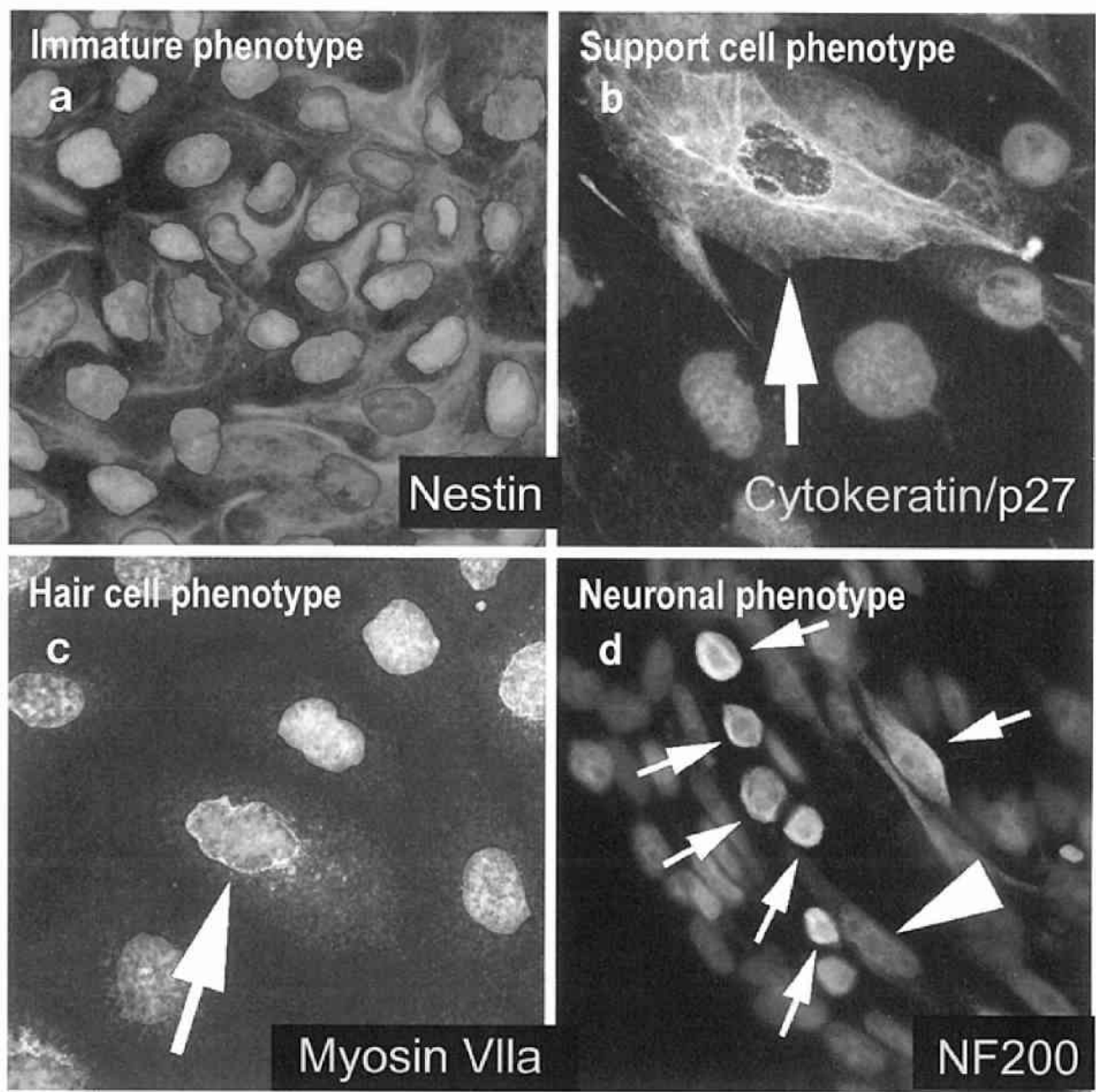

図 2 内耳感覚器前駆細胞

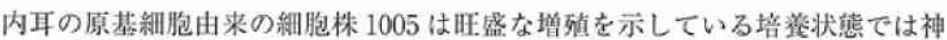
経幹細胞のマーカー蛋白であるネスチンを高率に発现し(a), 分化傾向になる

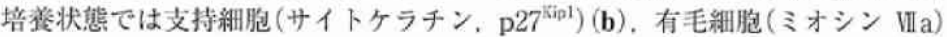
(c)，神経細胞(ニューロフィラメント 200)（d），のマーカー蛋白を発現する.

味では最も期待が持たれるものである，筆者らは, ラット胎児の耳の原器である耳胞から内耳前駆細 胞と考えるものを分離培養することに成功した(図 2) ${ }^{11)}$. この内耳前駆細胞の内耳有毛細胞への分化に ついても検討する価値がある.

以上の幹細胞は，いずれも内耳への細胞移植の有 力なドナー候補となりうるが, ES 細胞を使用する にせよ，胎児由来の細胞を使用するにせよ，倫理的 な問題を解決しなくてはならない.このような幹細 胞にくらべ, 自己由来の間葉系幹細胞は倫理的な問 題は少ない. 間葉系幹細胞は骨髄から採取し, 自己 のものを利用することが可能であるからである．間 葉系幹細胞が内耳有毛細胞に誘導できれば, 比較的 近い将来の臨床応用の可能性も考えられる.これら
の内耳への細胞移植概念図を図 3 に示す.

以下に各幹細胞を用いた内耳細胞移植研究の概要 または結果を示す。

\section{1. 胚性幹細胞}

胚性幹細胞 ( $\mathrm{ES}$ 細胞) ES 細胞は, 初期胚中の全能 性幹細胞と同様に, 個体を構成するすべての細胞に 分化する能力を保持し, 無制限に増やすことが出来 る.

ヒト ES 細胞に対する期待は大きいが, 臨床応用 を考えたときには，第一に第 3 者の細胞であるから 免疫抑制剤が必要, 第二に奇形腫の可能性, 第三に 発生早期の細胞は得やすいが発生後期の細胞を得る のが難しいなどの問題がある. 


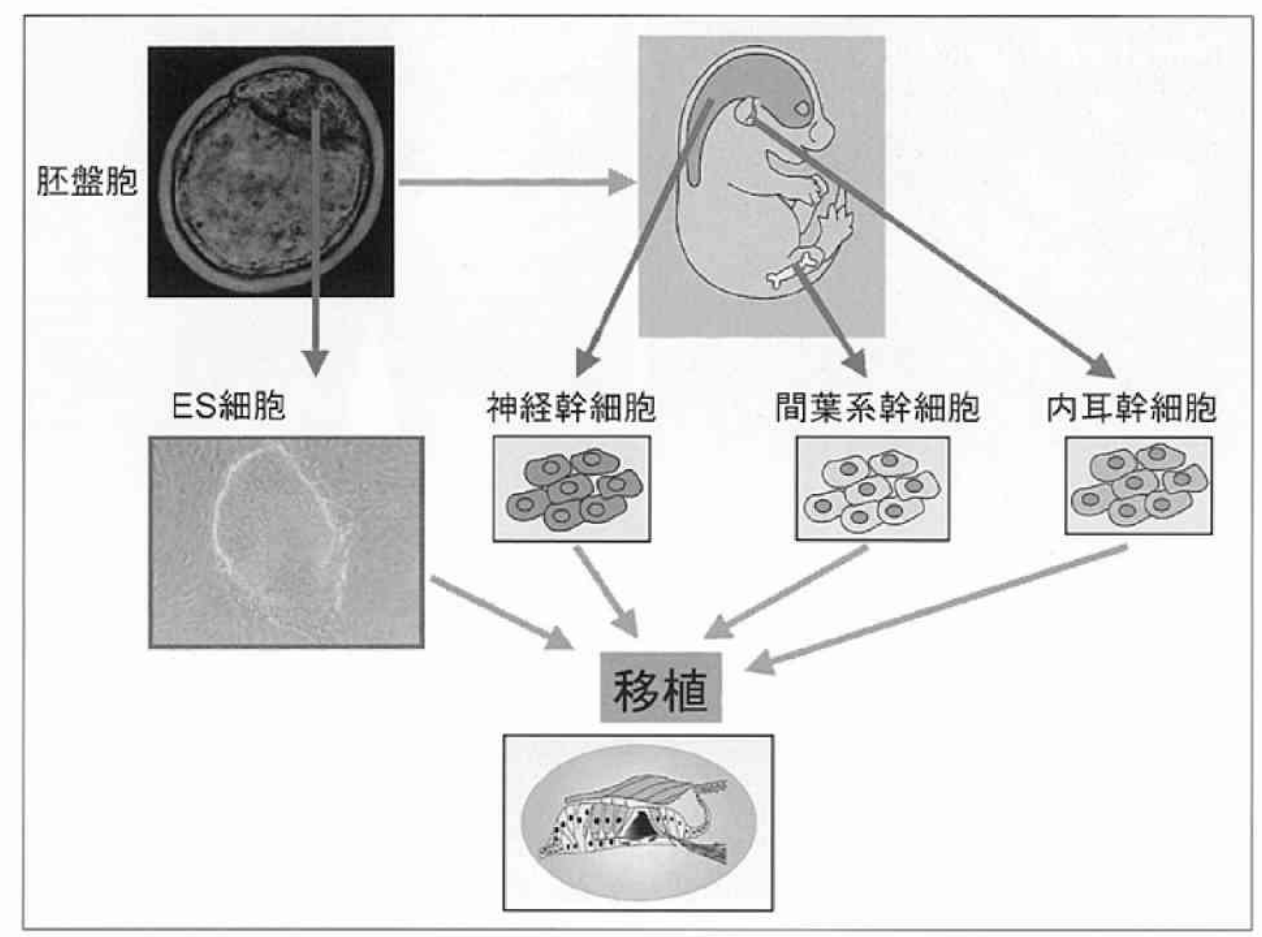

図 3 内耳細胞移植の概念図

技術的な問題以外に倫理面の問題が大きく，特に ヒトの場合, どの段階から生命を持った人間として 扱うべきか，ES紐胞樹立に必要な胚をどのように して入手するか，遺伝子操作を行ってよいのか，な ど, 議論の対象となる点は多い.

\section{ES 誘導細胞}

$\mathrm{ES}$ 細胞は, 生体のすべての細胞に分化する能力 を持つ細胞であるが，ある細胞への分化を選択的に 誘導したり, 選別したりする方法はわずかな細胞種 でしか知られていない．内耳有毛細胞も，もちろん その誘導方法はまったく明らかになっていないが, 蝸牛管が皮䖉外肧葉のなかに形成される耳プラコー ドに由来することを考えると, 外胚葉への誘導を ES 細胞から内耳有毛細胞への誘導の第 1 段階と考 えるのが妥当である.

ES 細胞の分化誘導は肧葉体を経由した誘導する 方法と, 経由しないで間質細胞と共培養して誘導 する方法にわけられる. ES 細胞を間質系細胞株上 (PA6) で培養することで, ES 細胞から肧葉体を経 ず，直接，皮成外胚葉の細胞を誘導することが可能 である ${ }^{12)}$.
この SDIA 法とよばれる方法は, ラット胎児の頭 蓋骨から得られた紐胞(PA6) と ES 細胞の共培養に よって効率よく神経分化を誘導できる方法で，マウ スだけでなく、サル ES 細胞でも同じ方法が適応で きる、また，この培養液中に BMP-4 を添加するだ けで, 皮䖉外胚葉へも誘導できる.このことから, SDIA 法で誘導された ES 細胞は, ある時期には皮 䖉・神経の共通の祖先である未分化外肧葉に相当す る分化状態を経ていることが予想される.

筆者らの研究では, SDIA 法によって外胚葉方向 に誘導された ES 細胞をマウスの内耳に移植したと ころ，らせん神経節細胞を再生することが可能であ ることを明らかにした(未発表).

\section{3. 神経幹細胞}

筆者らは神経幹細胞の内耳一の移植実験を行っ $た^{10)}$. 新生ラット (生後 $2 \sim 3$ 日) の内耳に海馬由来 の神経幹細胞を移植し, 投与 $2 \sim 4$ 週間後の移植し た細胞の様子を観察した，その結果，蝸牛の鼓室 階, 前庭階, 蝸牛管の内部, 管沿壁に移植紐胞が一塊 となって見いだされ, 神経幹細胞が移植後数週間 たっても生着しつづけることがわかった，また，一 


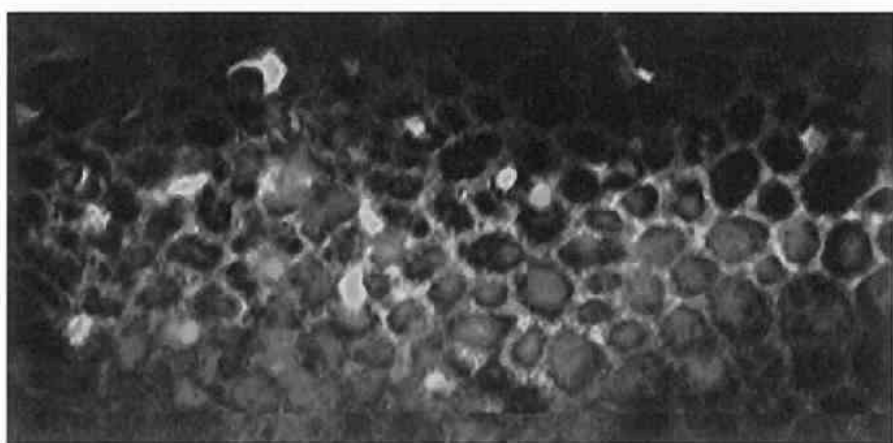

図 4 内耳に生着した神経幹細胞

移植神経幹細胞は前庭感覚上皮の上あるいは内部に入り込ん で生存している，Fアクチンの bundle 加らなる蜂柴梯構造 の内部に移植細胞が入り迄んでいる.

部に神経幹細胞が有毛細胞上に生着したり，蝸牛コ ルチ器内に侵入して一部有毛細胞に置き換わってい るのではないかという所見もみられた(図 1).

このような神経幹細胞移植は内耳以外にも脳, 網膜などですでに試みられているが，脳への移植に おいて，適度に第害を加えた場合が最も神経への分 化の効率がよかったことが報告されている，また， 網膜への移植においても無処置で移植を行った場合 よりもあらかじめ網膜に傷害を与えておいたほう が移植細胞の生着の効率がよいことが報告されてい $ろ^{13]}$.

そこで筆者らは，アミドグリコシド系抗生物質を 用いてあらかじめマウスに内耳障害を与え，障害さ れた内耳への神経幹細胞の移植を行い移植細胞の運 命を追った。

移植後 7 日目では移植細胞の大部分は内リンパ 腔，外リンパ腔内に集塊をなして存在し，一部は単 独で存在していた，移植後 14 日目，25 日目には移 植細胞は外リンパ空, 内リンパ空の全体にわたり内 側壁に沿う形で存在していた．さらに，一部の細胞 は螖牛軸の内部にも存在していた。

前庭, 蝸牛にわけて観察してみると, 前庭では 大部分の移植細胞が前庭感覚上皮の上または内部に 存在していた，細胞骨格構成蛋白である Fアクチ ンのマーカーであるファロイジンで染色すると，卵 形囊上皮に存在する移植細胞の大部分は F アクチ ンの蜂单状の構造に入り込む形で存在しており, 支 持細胞層のレベルに入り込んで生存していることが 示唆された $(\text { 図 4 })^{14)}$. 蝸牛では大部分の細胞は前庭
階, 鼓室階の内腔側に添う形で存在していたが, 一 部の細胞はコルチ器に存在しており, また, 鼓室階 からコルチ器の内部まで移植細胞が連なっている像 も観察され, 鼓室階からコルチ器の内部に移動して いることが推察された.

さらに，これらの移植細胞がどのように分化して いるのか免疫組織化学的手法を用いて解析した. そ の結果, 移植後 14 日あるいは 25 日の時点でグリア 細胞のマーカーである GFAP に陽性を示す細胞が 移植細胞全体の $90 \%$ と大部分を占めていた。一方, 神経細胞のマーカーとされる MAP2 に陽性を示す 細胞は約 $10 \%$ と少数であり，移植細胞のほとんど がグリア細胞に分化していたが

他方, 神経幹細胞のマーカーであるネスチンに 陽性を示す細胞が移植後 25 日の時点においても観 察された。これらのネスチン陽性細胞は集塊をなし て存在していた. また, 前庭の感覚上皮層内部に生 着している移植細胞の一部に, 内耳有毛細胞のマー カーであるミオシン VIIaに陽性を示す細胞が移植 後 14 日, 25 日の時点で観察され, 有毛細胞への分 化が示唆された. また, 外リンパ腔内に存在して いる細胞でミオシン VII に陽性を示す細胞は認めな かった.

今回の移植実験の結果, 神経幹細胞は内耳におい て少なくとも25日間は生存しうること，また，腫 瘍をつくることなしに感覚細胞層を含む上皮内に入 り込んで生存しうることが確認された，さらに数は 限られていたものの, 感覚上皮内に入り込んでいた 移植細胞の一部は有毛細胞のマーカーであるミオシ ンVIaに陽性を示し, 有毛細胞へ分化している可能 性が伺われた.

一方, 神経幹細胞の移植後の分化をみてみると, 外リンパ腔では移植細胞の大部分がグリア細胞に 分化しており, 神経細胞のマーカーに陽性を示した ものは一部であったのに対し, 内耳有毛細胞のマー カーに陽性を示した移植細胞はすべて内リンパ腔の 感覚細胞層に存在している細胞であり, 外リンパ腔 に生存している移植細胞で陽性を示す細胞はみられ なかった．移植細胞の周囲の環境が分化の方向を大 きく決定づけていることが示唆される.

有毛細胞の領域に生存していた移植細胞は, 有 
毛細胞のマーカーに陽性を示し, 有毛細胞へ分化し ている可能性が疑われた。このことから将来への内 耳有毛細胞の再生医療への応用を考えるにあたり， 神経幹細胞は再生医療に応用できるポテンシャルを 有していることが示唆される，しかしながら，現時 点ではミオシン VII に陽性を示す細胞は限られてお り，効率よく有毛細胞へ分化させることが今度の課 題である.

\section{4. 間葉系幹細胞}

骨䯕には造血幹細胞が存在し, 赤血球や白血球な どすべての血球細胞に分化することが従来より知ら れているが, 骨髄にはこのほかに骨揈間質細胞とよ ばれる付着系の細胞があり，そのなかに間葉系幹細 胞が存在することが明らかになっている.この間葉 系幹細胞は骨, 軟骨, 脂肪細胞, 筋肉など中胚葉系の 細胞に分化しうることが知られていたが, 近年この 間葉系幹細胞が中胚葉系だけでなく、神経細胞，肝 細胞など他の胚葉系の細胞にも分化しうることが報 告された。

再生移植医療を考えるにあたり，ドナー細胞をど のように供給するかという問題が常に存在している が, 間葉系幹細胞は患者本人の骨䯣から採取できる ことから再生医療の実用化に向けた細胞の供給源と して注目を集めている.

\section{5. 内耳感覚器前駆細胞}

内耳感覚器を構成する有毛細胞 · 支持練胞 · 蝸牛 神経節神経細胞は, いずれも胎生期の内耳原基耳胞 から発生するが, その 3 種類の細胞の in vivo での 発生系譜はいまだ不明な部分が多い、レトロウイル スを用いた細胞トレース法やレーザーを用いた有毛 細胞の再生実験から, 有毛細胞と支持細胞が共通の 前駆細胞から発生することが明らかにされているの みであり, 胎生幹細胞や神経幹細胞などのような多 能性を持つ細胞の存在が生体内で存在するか否かは いまだに明らかにされていない.

しかしながら，成長因子を添加した培地を用いた 分散培養系の実験では, 最終分裂後の内耳感覚上皮 から不動毛様の構造を持つ有毛細胞タイプの細胞に 分化する細胞群が, 不死化遗伝子を用いた分散培荃
系では有毛紐胞または支持細胞，神経細胞，グリア のマーカー蛋白を発現する細胞群が胎生期のみなら ず，成熟した内耳感覚上皮からも同定されている. これらの培養細胞を用いた研究から, 胎生初期の感 覚上皮内には有毛細胞や支持細胞, 神経細胞, グリ アの共通の前駆細胞が存在する可能性が示唆されて いた.

筆者らは, 細胞移植による内耳再生の可能性を 探るため, 胎生 12 日ラット内耳から不死化遺伝子 を用いることなく培養細胞系を樹立した。この時期 の内耳では螖牛の形成がはじまっておらず, 有毛細 胞や支持細胞に将来分化していく未分化な細胞が豊 富に存在すると考えられている，その細胞群から樹 立した, たった一つの細胞由来の細胞株 1005 は, 旺盛な増殖を示している培養状態では神経幹細胞の マーカー蛋白であるネスチンを高率に発現するが, 増殖が止まり，分化傾向になる培養状態では有毛細 胞(ミオシンVI, VII a), 支持細胞（サイトケラチン. $\mathrm{p} 27^{\mathrm{Kip} 1}$, Hes1), 神経細胞(ニューロフィラメント 200, MAP1)、グリア(A2B5, GFAP)のマーカー 蛋白を発現する細胞が出現した。この結果から細胞 株 1005 は多能性を持つ細胞すなわち，有毛細胞， 支持細胞，神経細胞，グリアに分化する能力を持つ 細胞であったことが示され, 内耳感覚器前駆細胞の 候補細胞と考えられる ${ }^{11}$.

この内耳前駆細胞を障害を与えたラットの内耳に 移植したところ，その細胞は内・外有毛細胞の層で 生着した、しかしながら、この細胞株 1005 が移植 先の生体内で多能性を発揮できるか否か, また，正 常の内耳発達過程において，このような性質を持つ 細胞がその多能性を発揮しているか否かは, 今後の 研究成果を待つ必要がある.

\section{内耳再生医療支援技術}

\section{1. 内耳への新しい薬物投与方法}

再生医療の目的は, 障害された生体組織の再生 あるいは代替を行うことである，再生医療が成り 立つには，(1) 障害を受けた組織(細胞)に代わりう る “細胞”を供給すること，(2) その細胞が生着す るための適切な環境 (“足場”)を提供すること, (3) 
“細胞”, “足場”が効率よく機能するための “環境 因子”を供給すること，この三つが重要な要素とな る。

細胞に関しては, 近年特に発展に著しい“幹細 胞” 技術が応用されている. 内耳再生医療を実現に 近づけるためには, 上記の幹細胞移植技術は有効な 手段と考えられる. しかし, いかに幹細胞医学が進 歩しても細胞が活動する周囲環境が適切に機能しな いと組織の再生は誘導されない.

組織(臓器)によっては適切な足場を供給するだ けで再生が誘導される場合もある. 耳鼻科領域で, 単純な鼓膜穿孔の場合, コラーゲン膜, ベスキチン 膜などを足場として置くだけで鼓膜が再生されるの も、この考えかたを応用したものである. しかし， 組織の再生能力が低い場合には, 細胞を提供し, 足 場をつくるだけでは組織再生は期待できない場合も ある.

そこで必要になるのが “環境因子”である．この “環境因子”の一種と考えられ再生医療で対象とな るものに, 細胞の増殖 - 分化促進作用を持つ細胞成 長因子 (growth factor：細胞增殖因子)などの物質 があげられる. 細胞成長因子は分子生物学や細胞生 物学などの進歩に伴って, その作用メカニズムが明 らかになるとともに, 遺伝子操作により大量生産が 可能となっている. 細胞の増殖や分化. 形態形成な どに働くこれらの因子を利用すれば, 組織の再生促 進が期待できる.

\section{2. 再生を促進する物質とその投与方法}

内耳に関してもこれまでいくつかの物質が有毛 細胞保護, または再生に有効であると報告されてい る.しかし, 細胞成長因子は一般には蛋白であり, 生体内では非常に不安定で, 生体に投与してもすぐ 代謝され, 期待する組織再生効果は得られないこと が多い.

またこれらの物質の投与方法として, 全身投与す る場合は内耳に作用させるためには大量頻回投与し か方法がなく, 薬物が他の細胞にも高濃度で作用す ることが考えられ, 副作用の原因となる可能性があ る. 理想的には必要な物質を必要な部位に, 必要な 量だけ，適切な期間投与することである，物質の濃
度を, 必要な場所で必要な期間にわたって有効值に 保つドラッグデリバリーシステム (DDS)の応用が 期待される.

\section{3. 薬物徐放化技術と内耳再生医療}

内耳など全身的な薬物投与効果の少ない部位で は，局所に，しかも薬物を少しずつ徐放できる技術 が必要である. 特に内耳有毛細胞の発達・再生に役 立つと考えられている細胞成長因子は, 現在ではま だ入手が困難な状況にあり，出来るかきりり少量で最 大限の効果が期待できる投与法の開発が望まれる.

これらの薬物の投与法の可能性を以下に示す.

\section{(1) 生体吸収性ゼラチンハイドロゲルを}

用いた薬物の徐放

薬物の徐放に, 生体吸収性ハイドロゲル (biodegradable hydrogel) を徐放キャリアとして用 いる方法が試みられている ${ }^{15)}$ 。このハイドロゲルは 徐放したい薬物 (主に蛋白質である)に対して刺激 が少なく, 安全性が確立されているため, 徐放キャ リアとして有用である. 薬物を効果的に局所に投与 するためには, 少なくとも数日間〜数週間の期間で 徐放するよう操作できることが必要である，また， 徐放キャリアが生体内に残存することは好ましくな く，最終的には生体内で吸収されることが要求され る. 徐放期間の調節に関しては, 徐放キャリアであ るハイドロゲルと薬物の間に生じる分子間相互作用 力が利用されている.

つまり, 生体内で薬物がハイドロゲルとの分子 間相互作用により，一定の期間局所にとどまり， 八 イドロゲルに分解酵素が作用することにより，それ と同時に薬物が徐々に放出される仕組みである。こ のハイドロケ゚ルには生体内での安全性と生体内での 吸収性,さらに徐放したい薬物との分子間親和性が 要求される.これらの要望を満たす材料として、コ ラーゲン, ゼラチン, ヒアルロン酸, アルギン酸など があり，それら単独またはいくつかの物質の組み合 わせで架橋を作製し徐放キャリアとして用いる.

\section{（2）徐放性ゼラチンハイドロゲルを用いた} 内耳への細胞成長因子の投与

筆者らは内耳へ薬物を徐放する研究として, BDNF (brain - derived neurotrophic factor)を組み 
込んだハイドロゲルをモルモットの正円空に留置し た. 留置後 3 日後に螖牛より外リンパ液を採取し, BDNF が内耳リンパ夜中に放出されているかどう かを確かめた，コントロールとして，BDNFを含 まないハイドロゲルのみの群, BDNFを直接正円 空から微小針で投与した動物と比較検討した。 その 結果, ハイドロゲルにBDNFを組み込んだ場合。 一定の濃度の BDNF が外リンバ液から検出された.

一方，BDNFを含まないハイドロゲルの場合は 当然のことであるが, 外リンパ液中にはBDNF は 検出されず，また急速投与した場合も 3 日後にはほ とんどBDNF は検出されず，代謝されたか脳毟随 液に流失したなどの可能性が考えられた.

以上の研究結果により, 徐放性のハイドロゲルに 組み込まれた BDNF は徐々に内耳に放出され，一 定の期間，内耳である濃度を保ちながらとどまるこ とが確認された．この徐放性ゼラチンハイドロゲル 含 BDNF の内耳に対する保護作用も, 内耳の有毛 細胞・神経細胞の数をカウントすることにより確か められ，内耳細胞の保護・再生に有用であることが 推測された。

\section{今後の展開}

内耳の特に有毛細胞が障害されるとそれは回復不 能であると考えられてきた。しかし，最近では障害 を受けた有毛細胞を回復させる，また再生を促す物 質がいろいろ報告されるようになってきた。一方, 内耳という特殊な解剖学的構造, 特殊なバリアー (blood cochlear barrier)などの存在により, 内耳に 薬物を局所投与することは難しいとされてきた。 ま た，仮にうまく投与されても脳脊漣液方向に流出し てしまうなど, 効果を発揮するには至らない結果が 報告されている.

今回紹介した徐放システム, 特に徐放性ハイドロ
ゲルを用いた薬物投与方法, さらにはナノテクノロ ジーを利用したナノカプセルの利用, 薬物徐放の可 能性のある細胞の移植などは, 内耳障害への新しい 治療方法への可能性を示すものとして期待される.

\section{文 献}

1) Cotanche DA : Regeneration of hair cell stereociliary bundles in the chick cochlea following severe acoustic trauma. Hear Res 30:181-195, 1987.

2) Forge A, Li L, Corwin JT, Nevill G : Ultrastructural evidence for hair cell regeneration in the mammalian inner ear. Science 259:1616-1619, 1993.

3) Iguchi F, Nakagawa T, Tateya I et al. : Trophic support of mouse inner ear by neural stem cell transplantation. Neuroreport $20: 77-80,2003$.

4) Ito J, Sakota T, Kato H, Hazama M, Enomoto M : Surgical considerations regarding cochlear implantation in the congenital malformed cochlea. Otolaryngol Head Neck Surg $121: 495-498,1999$.

5) Jorgensen JM, Mathiesen C : The avian inner ear. Continuous production of hair cells in vestibular sensory organs, but not in the auditory papilla. Naturwissenschaften 75 : 319-320, 1988.

6) Corwin JT, Cotanche DA : Regeneration of sensory hair cells after acoustic trauma. Science $240: 1772-1774,1988$.

7) Rubel EW, Dew LA, Roberson DW : Mammalian vestibular hair cell regeneration. Science $267: 701-707,1995$.

8) Evans MJ, Kaufman MH : Establishment in culture of pluripotential cells from mouse embryos. Nature 292 : 154-156, 1981.

9) Thomson JA et al. : Embryonic stem cell lines derived from human blastocysts. Science $282: 1145-1147,1998$.

10) Ito J. Kojima K, Kawaguchi S : Survival of neural stem cells in the cochlea. Acta Otolaryngol, $121: 140-142,2001$.

11) Kojima K, Tamura S, Nishida AT, Ito J : Generation of inner ear hair cell immunophenotypes from neurospheres obtained from fetal rat central nervous system in vitro. Acta Otolaryngol (Suppl) : 26-30, 2004.

12) Kawasaki $\mathrm{H}$ et al. : Induction of midbrain dopaminergic neurons from ES cells by stromal cell-derived inducing activity. Neuron 28:31-40, 2000.

13) Nishida $A$, Takahashi $M$, Tanihara $H$, Nakano I, Takahashi JB et al. : Incorporation and differentiation of hippocampusderived neural stem cells transplanted in injured adult rat retina. Invest Ophthalmol Vis Sci $41: 4268-4274,2000$.

14) Tateya I, Nakagawa T, Iguchi F, Kim TS, Endo T et al. : Fate of neural stem cells grafted into injured inner ears of mice. Neuroreport 14:1677-1681, 2003.

15) Tabata $Y$, Nagano A. Ikada $Y$ : Biodegradation of hydrogel carrier incorporating fibroblast growth factor. Tissue Engineering $5: 127-131,1999$. 